\title{
Effect of Photoconductivity Precursor Volume on Structural, Physical, Electrical and Optical Properties of Thin Layers of Cadmium Oxide (CdO) Nanostructures Produced Using Spray Pyrolysis Technique
}

\author{
Alireza Heidari ${ }^{1,2,3,4,{ }^{*}}$ \\ ${ }^{1}$ Faculty of Chemistry, California South University, 14731 Comet St. Irvine, CA 92604, USA \\ ${ }^{2}$ BioSpectroscopy Core Research Laboratory, California South University, 14731 Comet St. Irvine, CA 92604, \\ USA \\ ${ }^{3}$ Cancer Research Institute (CRI), California South University, 14731 Comet St. Irvine, CA 92604, USA \\ ${ }^{4}$ American International Standards Institute, Irvine, CA 3800, USA
}

\begin{abstract}
Thin layers of Cadmium Oxide $(\mathrm{CdO})$ are produced over glassy substrate by spray pyrolysis technique with precursor volumes of 50,75 and $100(\mathrm{ml})$. FESEM images of samples show the formation of nanometric structures and structural characterization of them resulted from XRD spectroscopy indicate the formation of cubic polycrystalline structure in growing layers with preferred direction of (111). Evaluating the optical properties of samples show that optical band gap of layers is reduced from 3.6 to $3.4(\mathrm{eV})$ by increasing the precursor volume and the optical absorption coefficient of samples is in UV region at about $10^{5}\left(\mathrm{~cm}^{-1}\right)$. Data analysis indicates that the produced sample in volume of $100 \mathrm{~mL}$ has the smallest penetration depth (smaller than $200 \mathrm{~nm}$ ) in UV region. On the other hand, thin layers of Cadmium Oxide (CdO) with various volumes of Cadmium acetate solution (40,50 and $70 \mathrm{ml}$ ) were deposited using spray pyrolysis technique over a glassy substrate. Samples were investigated using FESEM images, XRD and UV-Vis spectra as well as I-V characteristic. It was found that all samples were grew up with polycrystalline nanostructures along the preferred direction of (002). In addition, it was found that grew up sample in the volume of 50 (ml) are of optimum photoconductivity condition in visible range regarding optimum structural (largest crystallite size and lowest crystallite defect density) and optical (smallest band gap and highest light absorption) conditions.
\end{abstract}
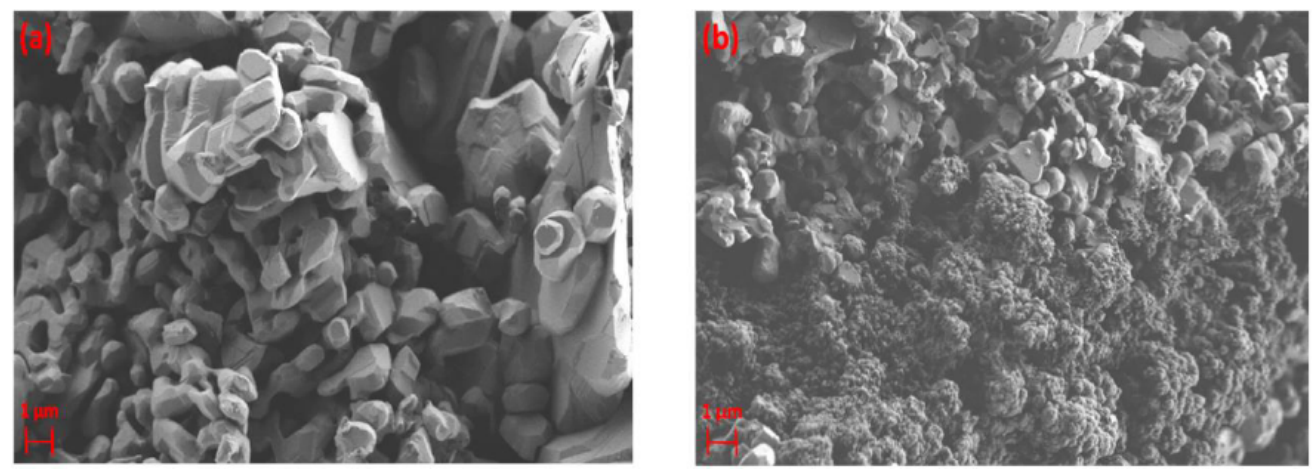

SEM images of thin layers of Cadmium Oxide ( $\mathrm{CdO}$ ) nanostructures (a) before and (b) after using spray pyrolysis technique with $50000 x$ zoom.

Keywords: Cadmium Oxide (CdO), Spray Pyrolysis Technique, Optical Properties, Penetration Depth, Photoconductivity, Nanostructures, Visible Light, Structural Properties, Physical Properties, Electrical Properties.

\section{INTRODUCTION}

Transparent, conductor oxide layers such as $\mathrm{SnO}_{2}$, $\mathrm{ZnO}$ and ITO are widely used as transparent electrode, window covers and in opto-electronic pieces. However, thin layers of Cadmium Oxide $(\mathrm{CdO})$ are mostly

"Address correspondence to this author at the Faculty of Chemistry, California South University, 14731 Comet St. Irvine, CA 92604, USA;

Tel: +1-775-410-4974

E-mail: Scholar.Researcher.Scientist@gmail.com; Alireza.Heidari@calsu.us interested due to having semi-conductive property with conductivity type $p$ and direct and wide band gap between 3.5 and $4(\mathrm{eV})$ and as a promising material for electrochromic pieces, lasers, electrode manufacturing in $\mathrm{p}-\mathrm{n}$ connections and layer type $\mathrm{p}$ for UV light detection [1-27]. Pure Cadmium Oxide ( $\mathrm{CdO})$ has specific resistivity of $10^{3}-10^{13}(\Omega . \mathrm{cm})$ at room temperature and by approaching to elemental proportionality, material becomes more dielectric. This increase in resistivity is due to reduction of hole density 
that is expected in a pure and complete crystal with wide band gap [28-71].

The aim of the current study is synthesizing thin layers of Cadmium Oxide ( $\mathrm{CdO}$ ) by spray pyrolysis technique and investigating the effect of variation of precursor volume on optical and photoconductivity properties of the layers.

Cadmium Oxide $(\mathrm{CdO})$ is one of the rare inherent semi-conductors of type $P$ with a narrow band gap of about 1.2-2.1 (eV) which has a monoclinic structure with limited transparency in the region of visible light [72-104]. Thin layers of this material are frequently dark brown to black. This darkness is due to narrow band gap and direct transitions between bands [105-125]. This fact leads to high absorption of visible light and can be used in optical pieces such as solar cells. In addition, this material is considered due to abundance of raw material, non-toxicity, easy production and ability to change and optimizing its physical properties using various physical and chemical methods such as chemical vapor deposition [117-125], spray pyrolysis [118-123] and so on. This material is one of the important mineral oxides for applying in pieces such as solar cells, electrochromic pieces and gaseous sensors due to its availability, high absorption rate and low cost [104-107].

In the current research, cost effective spray pyrolysis technique was used to investigate photoconductivity of Cadmium Oxide (CdO) thin layers with various volumes of spray solution.

\section{MATERIALS AND EXPERIMENTAL TECHNIQUES, METHODS AND WORK DETAILS}

To prepare thin layers of Cadmium Oxide (CdO), Cadmium acetate powder was solved in deionized water and 0.15 (M) Cadmium acetate solution was prepared. Then, this solution was sprayed over glassy substrate in various volumes $(40,50,70 \mathrm{ml})$ corresponding to samples of V1, V2, V3-to prepare the considered layers. It is expected that in pyrolysis process, the following chemical reaction mechanism happens [108-115]:

\section{$\mathrm{Cd}\left(\mathrm{CH}_{2} \mathrm{COO}\right)_{2} \cdot \mathrm{H}_{2} \mathrm{O}+\mathrm{H}_{2} \mathrm{O} \rightarrow \mathrm{CdO}+2 \mathrm{CH}_{3} \mathrm{COOH}+\mathrm{H}_{2} \mathrm{O}$}

During each step, cleaned substrates were heated up to $440^{\circ} \mathrm{C}$ in spray device and then, solution was sprayed under air pressure (1.1 bar). In this process, distance of sprays from substrates was $35(\mathrm{~cm})$.
Structural analysis of samples was performed by XRay Diffraction device (XRD, Brucker AXS) with CuKa spectral line emission $(1.5405 \AA)$ and the surface morphology of samples were investigated by Scanning Electron Microscopy (FESEM Hitachi S.4160). Optical characteristics of layers were measured using passed and absorbed spectra by optical spectroscopy (Shimadzu UV-Vis 1800) in the range of $300-1100$ (nm).

Thin layers of Cadmium Oxide (CdO) were synthesized over glass by spray pyrolysis technique. The precursor used for spraying was produced from Cadmium chloride hexahydrate powder with various volumes of two times de-ionized water. In the current research, spray distance from hot plate surface was 35 $(\mathrm{cm})$, deposition rate was $10(\mathrm{ml} / \mathrm{min})$, precursor molar concentration was $0.1(\mathrm{M})$, substrate temperature was $410^{\circ} \mathrm{C}$ and three samples of $\mathrm{V} 1, \mathrm{~V} 2$ and V3 were produced by volume of 50,75 and $100(\mathrm{ml})$, respectively.

For structural characterization of samples, X-Ray Diffraction (XRD) was performed by D8 AdvancedBruker XRD device dependent on spectral line CuKa with $0.15406(\mathrm{~nm})$ wavelength and $2 \theta$ between $10-70$ degrees. To measure the transited and reflected spectra, UV-Vis.-Shimadzo-1800 spectrophotometer device was used in the range of 300-1100 (nm). Surface morphology of samples was determined by Field Emission Scanning Electron Microscope device (FESEM; Hitachi S-4160).

\section{RESULTS AND DISCUSSIONS}

\subsection{Surface Morphology of Layers}

Figure (1) shows the obtained images from samples $\mathrm{V} 1, \mathrm{~V} 2$ and V3 in the scale of $500(\mathrm{~nm})$ from top (left side) and cross section (right side) for determining the thickness of samples. As can be observed, increasing the precursor volume of spray leads to more surface porosity of samples with larger gradation as well as larger thickness $(220,313$ and $275 \mathrm{~nm}$, respectively).

Figure (2) shows SEM images of samples in the scales of 5 microns and $500(\mathrm{~nm})$. Although the images for V1 and V3 samples show uniform surface along with some grains with 50 and $100(\mathrm{~nm})$, respectively, V2 sample is of porous surface along with woven fibers and mud-like particles that differentiate it from two other sample. 

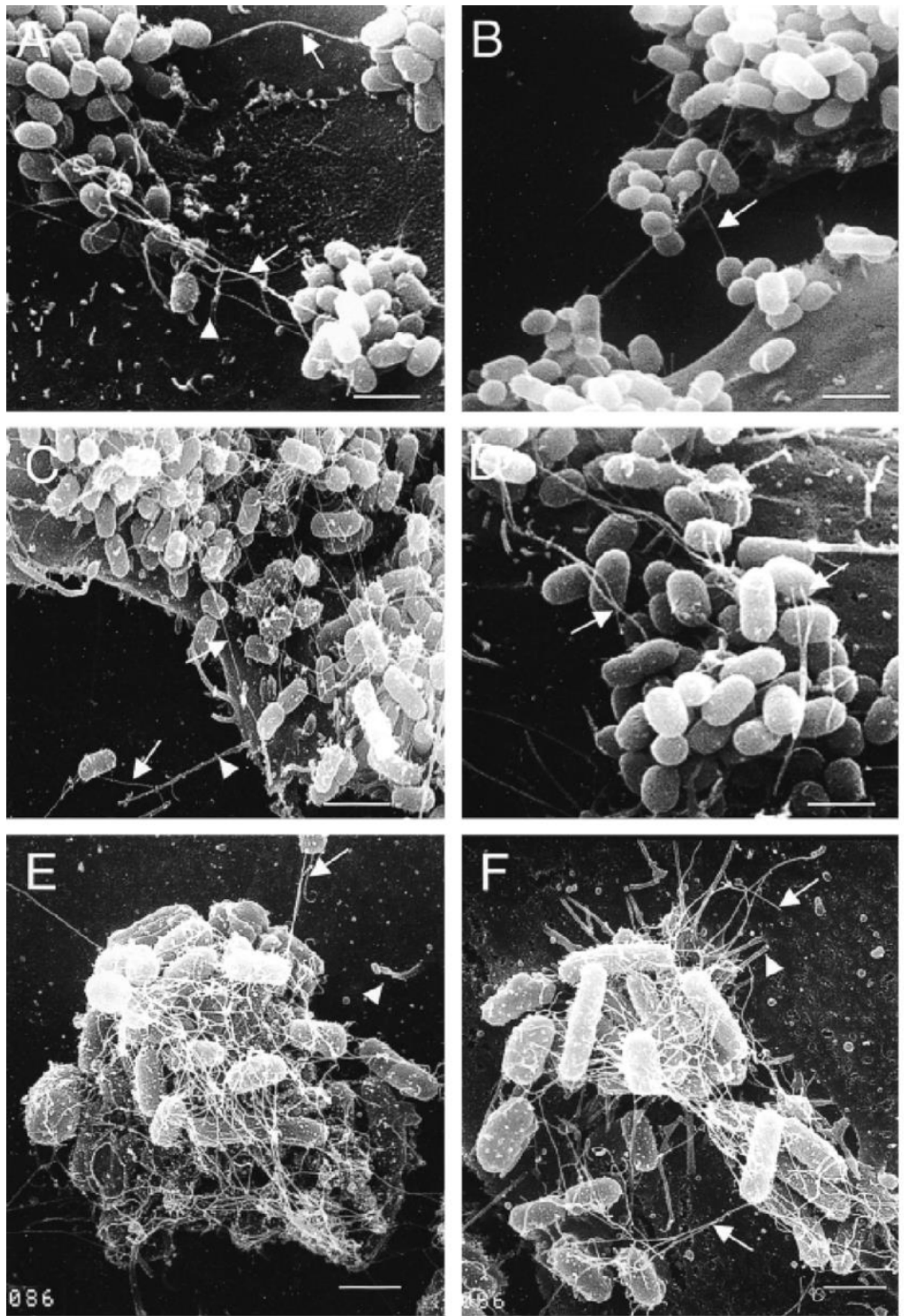

Figure 1: FESEM images of samples $\mathrm{V} 1, \mathrm{~V} 2$ and $\mathrm{V} 3$. 

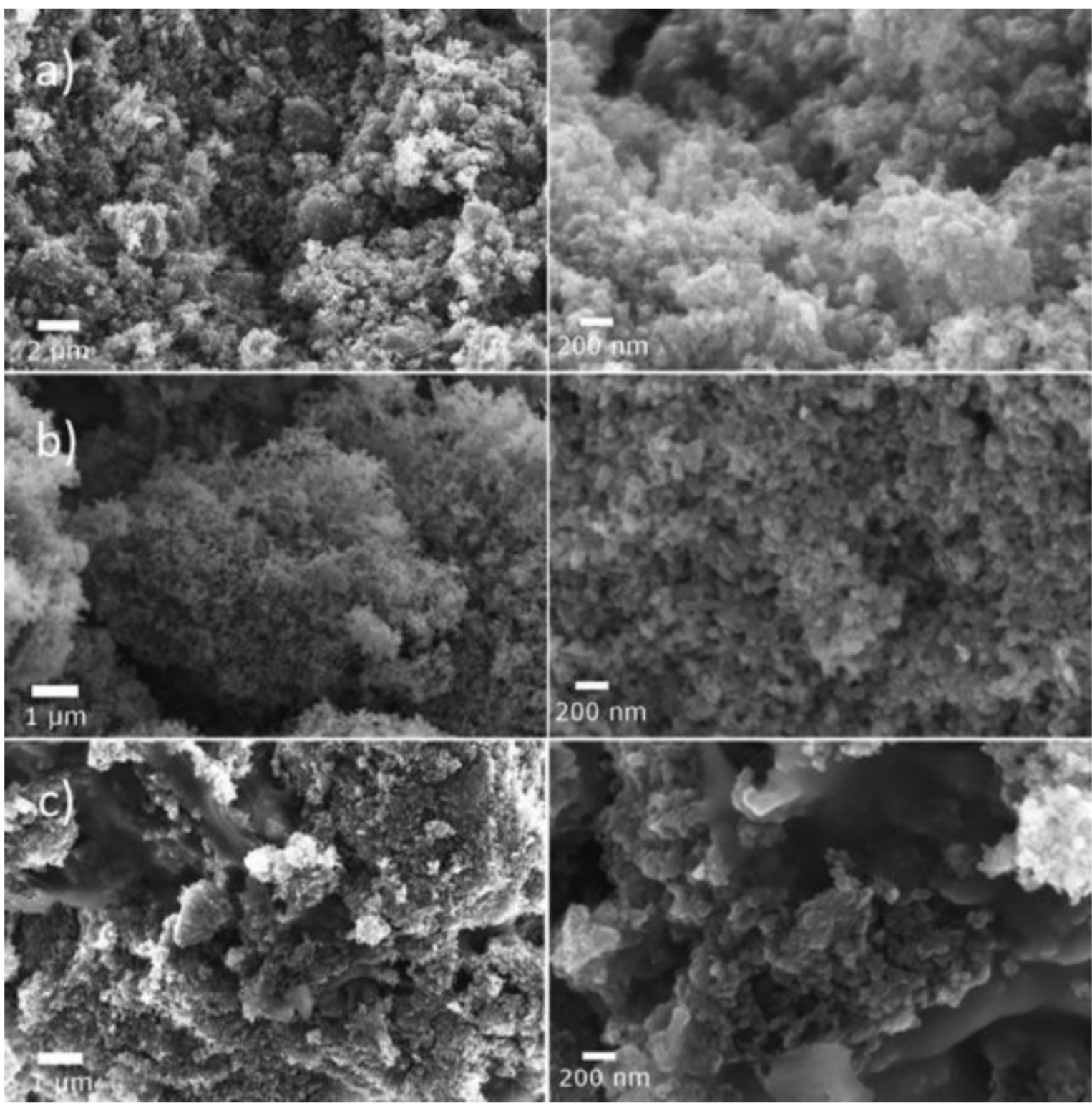

Figure 2: SEM image of thin layers of Cadmium Oxide $(\mathrm{CdO})$ for samples prepared in various volumes.

\subsection{Structural Properties}

Figure (3) shows XRD spectra for grew up samples with various volumes. The obtained results show that all three samples only have been grew up with a cubic polycrystalline phase of Cadmium Oxide $(\mathrm{CdO})$ in the preferred direction of (111).

Table (1) summarizes the detailed data related to XRD spectra for various samples, in addition to Full Width at Half Maximum (FWHM). The results indicate that by increasing the volume, spectral width of peak (111) is reduced, which can be due to variation of crystalline defects because of thickness variation during growing up [116-123].

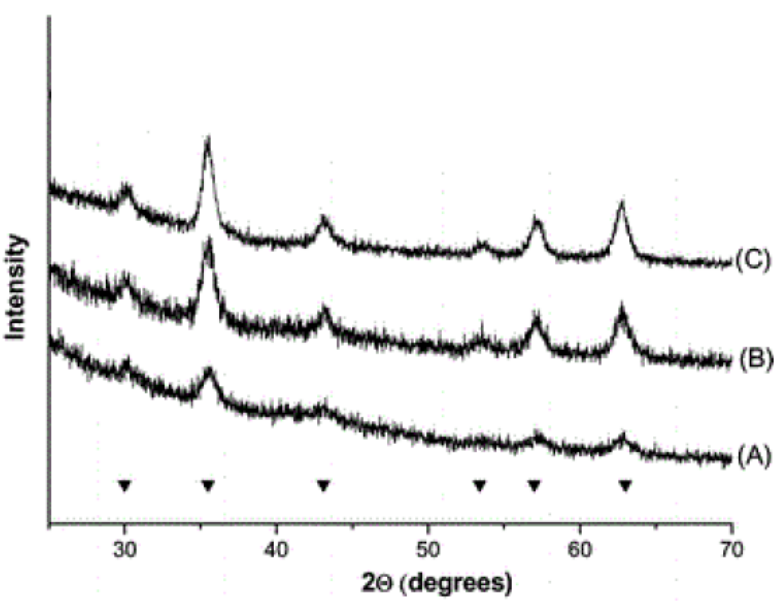

Figure 3: XRD spectrums for investigated Cadmium Oxide (CdO) samples. 
Table 1: XRD Spectrums Data for Various Samples and their Analyses using Scherrer Equation Related to Peak (111)

\begin{tabular}{|c|c|c|c|}
\hline $\mathbf{D}(\mathbf{n m})$ & $\mathbf{2 \theta}$ (Degree) & FWHM (Degree) & Sample \\
\hline \hline 21.23 & 41.27 & 0.59 & V1 \\
\hline 21.56 & 41.63 & 0.55 & V2 \\
\hline 21.97 & 41.77 & 0.51 & V3 \\
\hline
\end{tabular}

The fourth column in the table shows the size of crystallites in the grew up samples which can be calculated by Scherrer equation:

$D=\frac{0.9 \lambda}{B \cos \theta}$

where, $\lambda$ is $X$-Ray wavelength, $\beta$ is full width at half maximum and $\theta$ is Bragg's angle of diffraction.

Regarding the results listed for crystallite size in Table (1), it can be seen that the crystallite size is increase by increase in the volume of sample. These variations affect the optical properties of samples as shown in the following sections [124, 125].

XRD spectrums of samples are shown in Figure (4). Diffraction curves of samples indicate that they are of polycrystalline structure with monoclinic structure and principal planes of (002) and (111) located at angles of $35.56^{\circ}$ and $38.74^{\circ}$. The results indicate that V2 sample with solution volume of $50 \mathrm{ml}$ is of weaker peaks at directions of (202) and (020) at angles of $48.86^{\circ}$ and $53.85^{\circ}$, respectively. The presence of these peaks along with relative intensity of the major peaks indicate that crystalline structure improves compared to other samples.

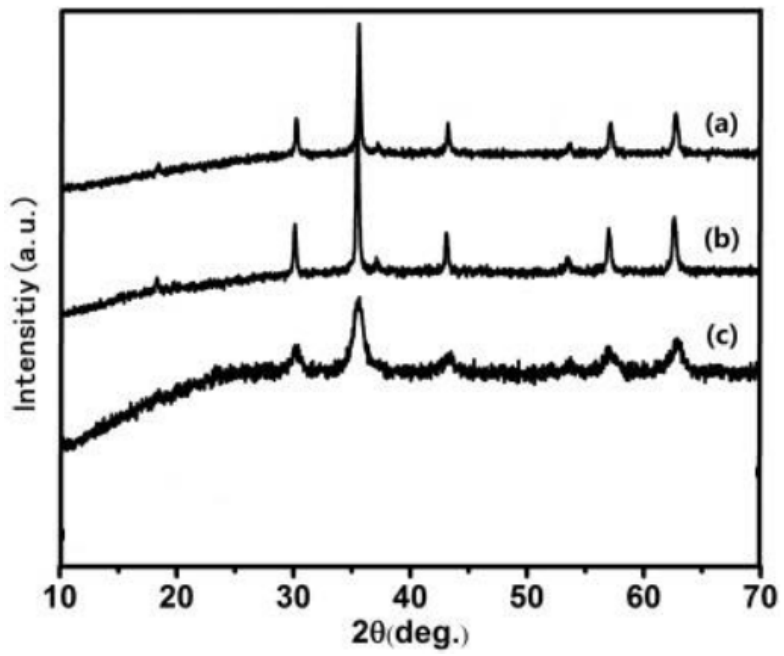

Figure 4: XRD spectrums of Cadmium Oxide (CdO) layers with various volumes of solution.
For more accurate investigation of structural properties, crystallite size (D), dislocation density $(\delta)$ and crystalline strains $(\varepsilon)$ are calculated [111-117]:

$\delta=\frac{1}{D^{2}}$

$\varepsilon=\frac{\lambda}{D \sin \theta}-\frac{\beta}{\tan \theta}$

where, $\beta$ is half width at full maximum, $D$ is crystallite size, $\theta$ is Brug angle and $\lambda$ is $X$-Ray wavelength. Results of these calculations are listed in Table (2).

Table 2: Calculated Structural Properties for the Preferred Peak (002)

\begin{tabular}{|c|c|c|c|}
\hline$\varepsilon\left(\times 10^{-3}\right)$ & $\delta\left(\times 10^{-2} \mathrm{~nm}^{-2}\right)$ & $D(\mathrm{~nm})$ & Sample \\
\hline \hline 2.69 & 0.597 & 17.49 & $\mathrm{~V} 1$ \\
\hline 2.31 & 0.323 & 19.93 & $\mathrm{~V} 2$ \\
\hline 3.81 & 0.499 & 15.37 & $\mathrm{~V} 2$ \\
\hline
\end{tabular}

\subsection{Optical Properties}

Figure (5) shows optical transition and reflection spectra for layers as a function of incident wavelength. According to experimental data, it can be seen that transition spectrums of layers in visible region is reduced from $55 \%$ to $30 \%$ by increasing the precursor volume. This reduction can be mainly due to increasing the thickness of investigated layers. The results of reflection spectrums of layers indicate that sample V3 with the highest surface porosity is of lowest reflection in visible region (about 1.5\%), as expected

In order to determine direct band gap $(\mathrm{Eg})$ of samples, the following equation can be used:

$(a h v)^{2}=A\left(h v-E_{g}\right)$

By illustrating $(a h v)^{2}$ in terms of hv and determining intercept on the horizontal axis for zero optical absorption $(a=0)$ in high energy region, band gap can 

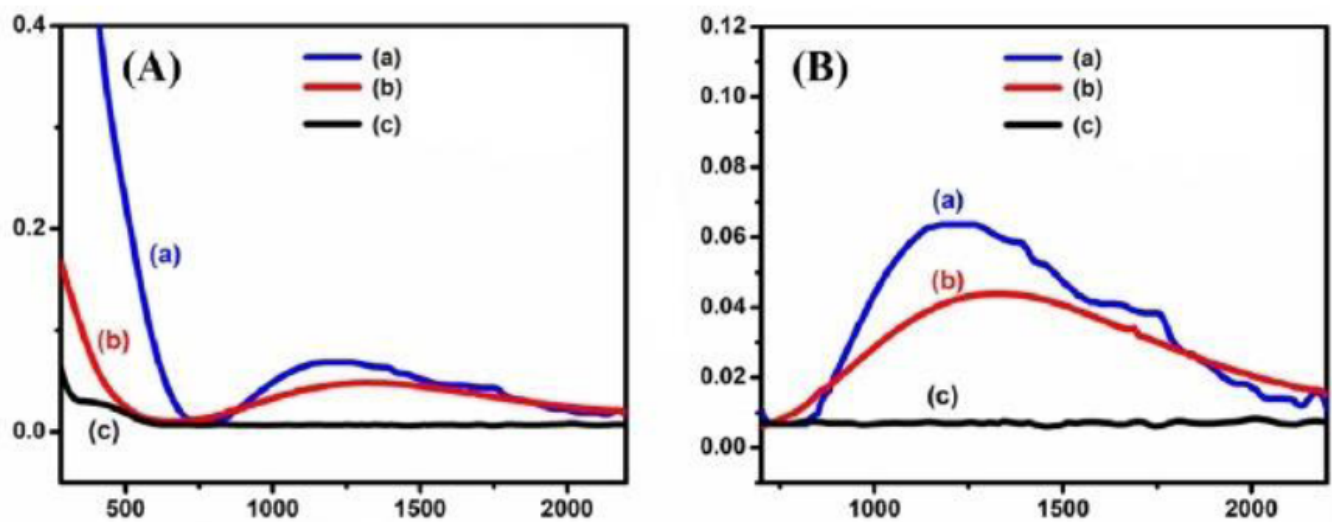

Figure 5: Optical (a) transition and (b) reflection spectra for samples.

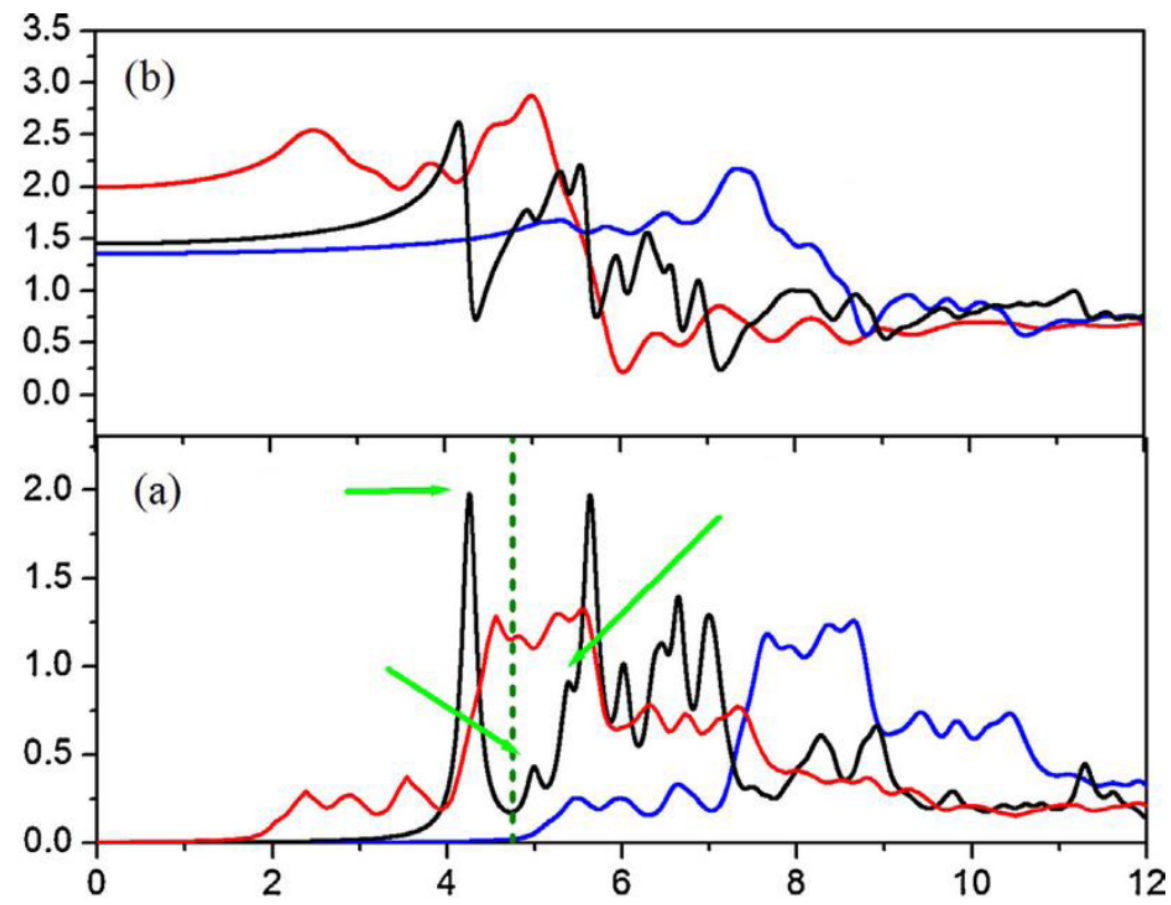

Figure 6: Direct optical (a) absorption spectrums and (b) band gap for the investigated samples.

be obtained. Figures (6.a) and (6.b) show experimental data related to absorption spectrums of layers and the results related to this analysis (Eq. (4)) and variations of band gap in the samples, respectively. The appendix image in Figure (6.b) indicates the variation of optical band gap of samples against precursor volume. As can be observed, band gap is reduced from 3.6 to $3.4(\mathrm{eV})$ as precursor volume is increased. This reduction can be attributed to reduction of effectiveness of quantum limitation in nanostructures of these layers, regarding the increase in crystallite size (which is in good agreement with FESEM images of samples).

One of the most important parameters for determining the optical properties of material is penetration depth of light into the layer that is inverse of absorption coefficient $(\alpha)$ of material. In order to determine this quality, the following equation can be used [118-123]:

$$
\alpha=2.3026 \frac{a}{t}
$$

where, $a$ is optical absorption of layer and $t$ is layer thickness.

Figure (7.a) shows theoretical curves related to absorption coefficient of these layers obtained from Eq. (5). The results indicate that all three samples are of high absorption coefficient $\left(\sim 10^{5} \mathrm{~cm}^{-1}\right)$ in energies 

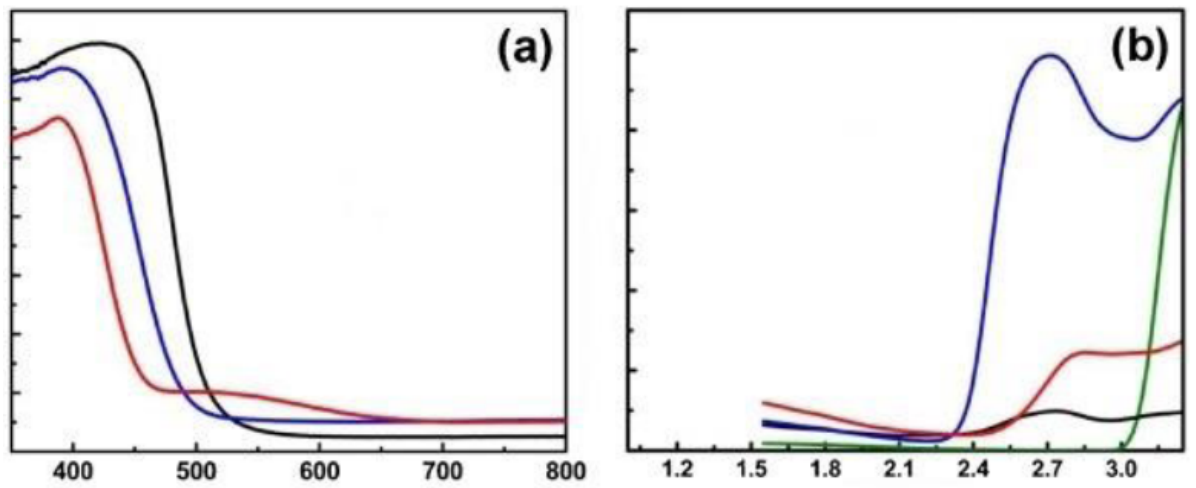

Figure 7: (a) absorption coefficient and (b) penetration depth in terms of wavelength.

higher than $\sim 3.5 \pm 0.1(\mathrm{eV})$ in UV light region. This absorption edge is in good agreement with optical band gap values of samples.

Figure (7.b) shows the variation of penetration depth $(\delta=1 / \alpha)$ in room temperature as a function of incident photon energy. As can be seen, in UV light region (wavelengths lower than $\sim 400 \mathrm{~nm}$ ), penetration depth of layers is lower than $200(\mathrm{~nm})$. It is expected that the main part of considered photons absorb by the layer regarding the layer thickness. This issue is of great importance in manufacturing the optical sensors in considered wavelengths. Regarding the obtained results from comparison of samples, sample V3 is of lowest penetration depth in UV light region.

Figure (8) shows optical transmittance spectrums of the under studied layers. It can be seen that in visible region of 400-700 (nm), V2 sample and V3 sample are of the lowest and highest transmittance, respectively. These variations may be largely due to relative

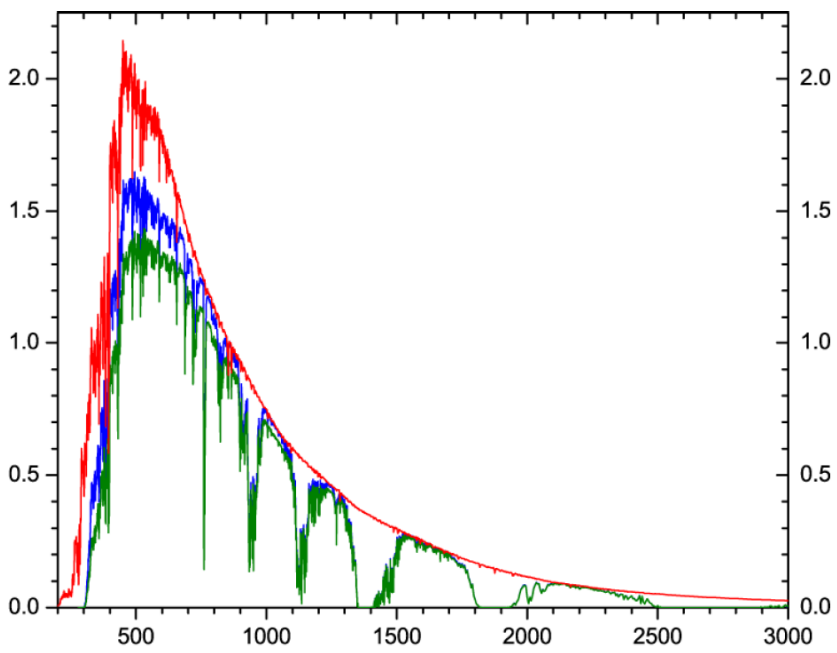

Figure 8: Transmittance optical spectrums of Cadmium Oxide $(\mathrm{CdO})$ thin layers grew up in various volumes. electrical conductivity of layers (Section 4.4) which is effective is relative amount of metal-like and or insulator-like of layers.

According to the reported results, Cadmium Oxide (CdO) layers are acted as a semiconductor with direct transition between bands so that during these transitions, absorption coefficient is a function of incident photon energy [118-125]. Figure (9) shows the variations of absorption spectra of layers against wavelength.

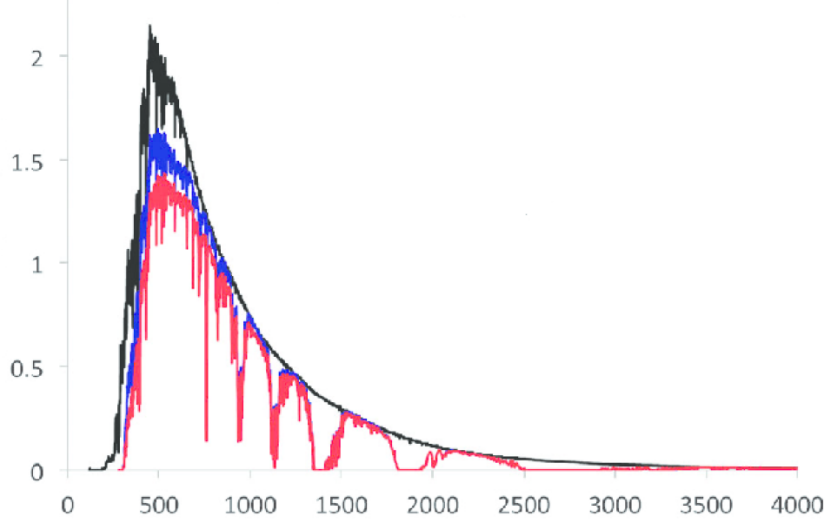

Figure 9: Absorption spectrums of under studied samples in terms of wavelength.

Since Cadmium Oxide $(\mathrm{CdO})$ is a semiconductor with direct transitions between bands, to determine optical band gap of samples, $(a h v)^{2}$ is drawn against $h v$ and data is extrapolated in linear region of high energy with horizontal axis as $a=0$. Figure (10) shows this curve in order to determine direct optical band gap and the attached figure shows the results obtained from this analysis related to band gap amounts. The results indicate that the sample with largest crystallite size (V2) has the smallest band gap (1.74 eV) and the sample with smallest crystallite size (V3) has the largest band 
gap (2.01 eV) which can be a reason for happening a quantum limitation in these samples.

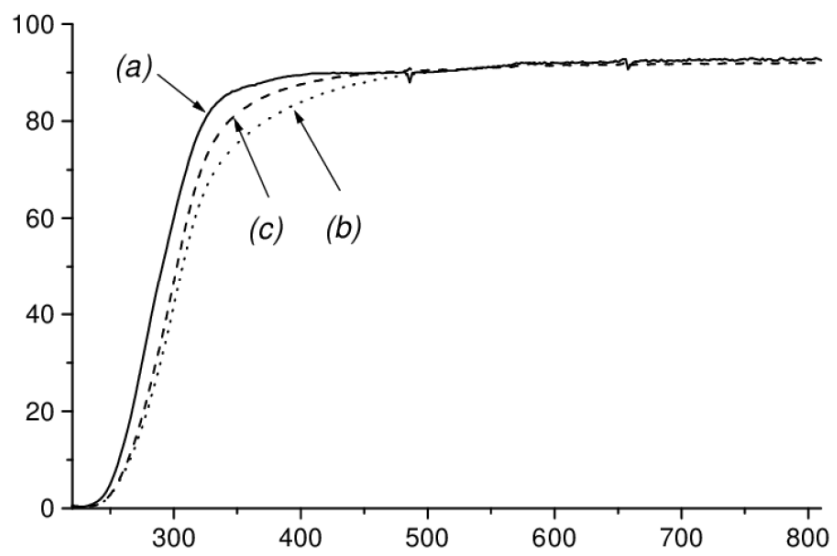

Figure 10: Analysis of optical data as a function of photon energy. The attached figure shows band gap of layers.

\subsection{Electrical Properties}

Figure (11) shows current-voltage curve of these samples. The results indicate that sample $\mathrm{V} 2$ has the highest electrical conductivity (metal-like property) while sample V3 has the lowest one (isolator-like property). This is in good agreement with optical transition behavior of layers.

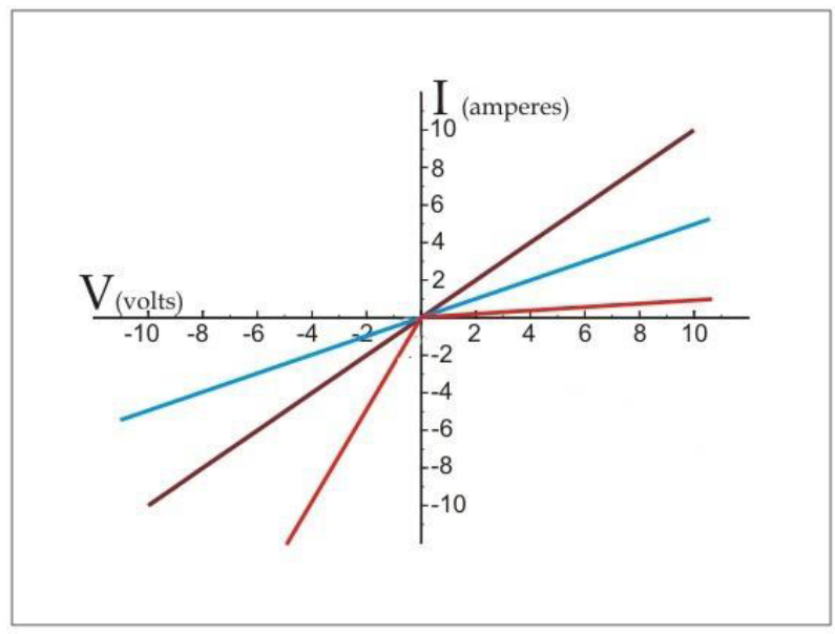

Figure 11: Current-voltage curve for samples grew up in darkness.

\subsection{Photoconductivity Properties}

To investigate photoconductivity of samples, the under studied samples were placed under visible light emission (halogen lamp). Figure (12) shows currentvoltage curve of samples under light. As can be observed, all three samples are reacted to the light and after emission, more electrical current passed through samples. This is an expected event due to producing electron - hole pairs in layers as a result of optical photon emission in $h v>E_{g}$. In order to compare optical sensitivity of these samples, the passed electrical current through samples in voltage of $3 \mathrm{~V}$ in darkness and under visible light emission are shown in Figure (13). As can be seen, sample V2 is of highest relative change of electrical current $\left(I_{\text {Light }} / I_{\text {Dark }}=11\right)$ and sample $\mathrm{V} 3$ is of lowest one $(=3)$. These variations may be due to the effect of various factors such as optical absorption, band gap, crystallite size and crystalline obliquity in the investigated layer.

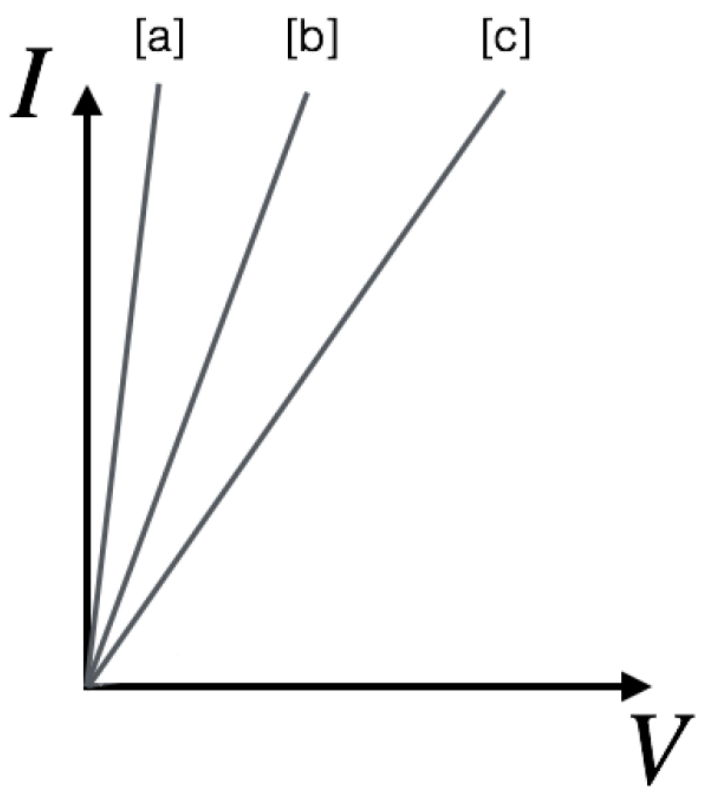

Figure 12: Current-voltage curve for samples subjected to visible light.

\section{CONCLUSION}

Cadmium Oxide ( $\mathrm{CdO}$ ) layers were deposited by spray pyrolysis technique in various volumes of 50,75 and $100(\mathrm{ml})$ over glass. FESEM images indicate that surface morphology of samples depend on variations of precursor volume spray and XRD spectrums indicates the polycrystalline structure of layers in preferred direction (111). Data analysis indicates that optimum crystallite size is for sample V3. Band gap of samples is between 3.4-3.6 (eV) so that sample $\mathrm{V} 3$ is of lowest band gap among other samples. Absorption coefficient in UV light region for all layers is in the order of $10^{5}$ $\left(\mathrm{cm}^{-1}\right)$ and sample V3 has the lowest penetration depth in this region.

The thin layers of Cadmium Oxide (CdO) nanostructures were deposited using spray pyrolysis technique with various volumes of spray solution over a 



Figure 13: Passed electrical current through investigated samples.

glassy substrate. FESEM images indicate that surface morphology of samples are dependent on the variations of solution volume and XRD spectrums of layers indicate that polycrystalline structures are grew up in preferred direction of (002). Data analysis indicate that at solution volume of $50(\mathrm{ml})$, crystallite size and crystallite defect densities are optimum and photoconductivity properties are improved. In visible light region, layers are of low optical transition and of optical band gap between 1.74-2.01 (eV) so that sample V2 has the lowest band gap among all samples. The obtained results indicate that band gap variations in these samples are controlled by crystallite size and under the effect of happening a quantum limitation. Photoconductivity results indicate that sample V2 is of highest optical sensitivity to visible light.

\section{ACKNOWLEDGEMENT}

This study was supported by the Cancer Research Institute (CRI) Project of Scientific Instrument and
Equipment Development, the National Natural Science Foundation of the United Sates, the International Joint BioSpectroscopy Core Research Laboratory Program supported by the California South University (CSU), and the Key project supported by the American International Standards Institute (AISI), Irvine, California, USA.

\section{REFERENCES}

[1] Kasiske, B.L.; Snyder, J.J.; Gilbertson, D.; Matas, A.J., 2003. Diabetes mellitus after kidney transplantation in the United States. Am. J. Transplant., 3, pp. 178-185. https://doi.org/10.1034/j.1600-6143.2003.00010.x

[2] Krentz, A.J.; Wheeler, D.C., 2005. New-onset diabetes after transplantation: A threat to graft and patient survival. Lancet., 365, pp. 640-642.

https://doi.org/10.1016/S0140-6736(05)17962-8

[3] Cosio, F.G.; Kudva, Y.; van der Velde, M.; Larson, T.S.; Textor, S.C.; Griffin, M.D.; Stegall, M.D., 2005. New onset hyperglycemia and diabetes are associated with increased cardiovascular risk after kidney transplantation. Kidney Int., 67 , pp. $2415-2421$. https://doi.org/10.1111/j.1523-1755.2005.00349.x

[4] Ekstrand, A.V.; Eriksson, J.G.; Grönhagen-Riska, C.; Ahonen, P.J.; Groop, L.C., 1992. Insulin resistance and insulin deficiency in the pathogenesis of posttransplantation 
diabetes in man. Transplantation, 53, pp. 563-569

https://doi.org/10.1097/00007890-199203000-00014

[5]

Nam, J.H.; Mun, J.I.; Kim, S.I.; Kang, S.W.; Choi, K.H.; Park, K.; Ahn, C.W.; Cha, B.S.; Song, Y.D.; Lim, S.K.; et al. 2001. beta-Cell dysfunction rather than insulin resistance is the main contributing factor for the development of postrenal transplantation diabetes mellitus. Transplantation, 71, pp. 1417-1423.

https://doi.org/10.1097/00007890-200105270-00011

[6] Nagaraja, P.; Sharif, A.; Ravindran, V.; Baboolal, K., 2014. Long-term progression of abnormal glucose tolerance and its relationship with the metabolic syndrome after kidney transplantation. Transplantation, 97, pp. 576-581. https://doi.org/10.1097/01.tp.0000438202.11971.2e

[7] Lee, H.C., 2012. Post-renal transplant diabetes mellitus in korean subjects: Superimposition of transplant-related immunosuppressant factors on genetic and type 2 diabetic risk factors. Diabetes Metab. J., 36, pp. 199-206.

https://doi.org/10.4093/dmj.2012.36.3.199

[8] Unwin, N.; Shaw, J.; Zimmet, P.; Alberti, K.G., 2002. Impaired glucose tolerance and impaired fasting glycaemia: The current status on definition and intervention. Diabet. Med., 19, pp. 708-723.

https://doi.org/10.1046/j.1464-5491.2002.00835.x

[9] Expert Committee on the Diagnosis and Classification of Diabetes Mellitus. Report of the expert committee on the diagnosis and classification of diabetes mellitus. Diabetes Care 2003, 26, pp. S5-S20.

https://doi.org/10.2337/diacare.26.2007.S5

[10] Sharif, A.; Moore, R.H.; Baboolal, K., 2006. The use of oral glucose tolerance tests to risk stratify for new-onset diabetes after transplantation: An underdiagnosed phenomenon. Transplantation, 82, pp. 1667-1672. https://doi.org/10.1097/01.tp.0000250924.99855.42

[11] Uchida, J.; Iwai, T.; Kuwabara, N.; Machida, Y.; Iguchi, T.; Naganuma, T.; Kumada, N.; Kawashima, H.; Nakatani, T., 2011. Glucose intolerance in renal transplant recipients is associated with increased urinary albumin excretion. Transpl. Immunol., 24, pp. 241-245.

https://doi.org/10.1016/j.trim.2011.02.001

[12] Matthews, D.R.; Hosker, J.P.; Rudenski, A.S.; Naylor, B.A.; Treacher, D.F.; Turner, R.C., 1985. Homeostasis model assessment: Insulin resistance and beta-cell function from fasting plasma glucose and insulin concentrations in man. Diabetologia, 28, pp. 412-419. https://doi.org/10.1007/BF00280883

[13] Levy, J.C.; Matthews, D.R.; Hermans, M.P., 1998. Correct homeostasis model assessment (HOMA) evaluation uses the computer program. Diabetes Care, 21, pp. 2191-2192. https://doi.org/10.2337/diacare.21.12.2191

[14] Matsuo, S.; Imai, E.; Horio, M.; Yasuda, Y.; Tomita, K.; Nitta, K.; Yamagata, K.; Tomino, Y.; Yokoyama, H.; Hishida, A., 2009. Collaborators developing the Japanese equation for estimated GFR. Revised equations for estimated GFR from serum creatinine in Japan. Am. J. Kidney Dis., 53, pp. 982992.

https://doi.org/10.1053/j.ajkd.2008.12.034

[15] Gabir, M.M.; Hanson, R.L.; Dabelea, D.; Imperatore, G.; Roumain, J.; Bennett, P.H.; Knowler, W.C., 2000. The 1997 American Diabetes Association and 1999 World Health Organization criteria for hyperglycemia in the diagnosis and prediction of diabetes. Diabetes Care, 23, pp. 1108-1112. https://doi.org/10.2337/diacare.23.8.1108

[16] Cole, E.H.; Johnston, O.; Rose, C.L.; Gill, J.S., 2008. Impact of acute rejection and new-onset diabetes on long-term transplant graft and patient survival. Clin. J. Am. Soc. Nephrol., 3, pp. 814-821. https://doi.org/10.2215/CJN.04681107

[17] Bloom, R.D.; Crutchlow, M.F., 2008. New-onset diabetes mellitus in the kidney recipient: Diagnosis and management strategies. Clin. J. Am. Soc. Nephrol., 3, pp. S38-S48. https://doi.org/10.2215/CJN.02650707

[18] Briggs, J.D., 2001. Causes of death after renal transplantation. Nephrol. Dial. Transplant., 16, pp. 15451549.

https://doi.org/10.1093/ndt/16.8.1545

[19] Levitan, E.B.; Song, Y.; Ford, E.S.; Liu, S., 2004. Is nondiabetic hyperglycemia a risk factor for cardiovascular disease? A meta-analysis of prospective studies. Arch. Intern. Med., 164, pp. 2147-2155. https://doi.org/10.1001/archinte.164.19.2147

[20] Stattin, P.; Björ, O.; Ferrari, P.; Lukanova, A.; Lenner, P. Lindahl, B.; Hallmans, G.; Kaaks, R., 2007. Prospective study of hyperglycemia and cancer risk. Diabetes Care, 30, pp. 561-567. https://doi.org/10.2337/dc06-0922

[21] de Vegt, F.; Dekker, J.M.; Ruhé, H.G.; Stehouwer, C.D. Nijpels, G.; Bouter, L.M.; Heine, R.J., 1999. Hyperglycaemia is associated with all-cause and cardiovascular mortality in the Hoorn population: The Hoorn Study. Diabetologia, 42, pp. 926-931.

https://doi.org/10.1007/s001250051249

[22] Pham, P.T.; Pham, P.M.; Pham, S.V.; Pham, P.A.; Pham, P.C., 2011. New onset diabetes after transplantation (NODAT): An overview. Diabetes Metab. Syndr. Obes., 4, pp. 175-186.

https://doi.org/10.2147/DMSO.S19027

[23] Shivaswamy, V.; Boerner, B.; Larsen, J., 2016. PostTransplant Diabetes Mellitus: Causes, Treatment, and Impact on Outcomes. Endocr. Rev., 37, pp. 37-61. https://doi.org/10.1210/er.2015-1084

[24] World Heal Organ (WHO). Global Status Report on Noncommunicable Diseases 2014; World Heal Organ: Geneva, Switzerland, 2014; p. 176.

[25] Mozaffarian, D.; Benjamin, E.J.; Go, A.S.; Arnett, D.K.; Blaha, M.J.; Cushman, M.; Das, S.R.; De Ferranti, S.; Després, J.P.; Fullerton, H.J.; et al., 2016. Executive summary: Heart disease and stroke statistics-2016 update: A Report from the American Heart Association. Circulation, 133, pp. 447-454.

https://doi.org/10.1161/CIR.0000000000000366

[26] Stanhope, K.L.; Schwarz, J.M.; Keim, N.L.; Griffen, S.C.; Bremer, A.A.; Graham, J.L.; Hatcher, B.; Cox, C.L.; Dyachenko, A.; Zhang, W.; et al., 2009. Consuming fructosesweetened, not glucose-sweetened, beverages increases visceral adiposity and lipids and decreases insulin sensitivity in overweight/obese humans. J. Clin. Investig., 119, pp. 1322-1334.

https://doi.org/10.1172/JCl37385

[27] Stanhope, K.L.; Havel, P.J., 2008. Fructose consumption: Potential mechanisms for its effects to increase visceral adiposity and induce dyslipidemia and insulin resistance. Curr. Opin. Lipidol., 19, pp. 16-24.

https://doi.org/10.1097/MOL.0b013e3282f2b24a

[28] Stanhope, K.L., 2016. Sugar consumption, metabolic disease and obesity: The state of the controversy. Crit. Rev. Clin. Lab. Sci., 53, pp. 52-67. https://doi.org/10.3109/10408363.2015.1084990

[29] Softic, S.; Cohen, D.E.; Kahn, C.R., 2016. Role of Dietary Fructose and Hepatic De Novo Lipogenesis in Fatty Liver Disease. Dig. Dis. Sci., 61, pp. 1282-1293. https://doi.org/10.1007/s10620-016-4054-0

[30] Mirtschink, P.; Jang, C.; Arany, Z.; Krek, W., 2018. Fructose metabolism, cardiometabolic risk, and the epidemic of coronary artery disease. Eur. Heart J., 39, pp. 2497-2505. https://doi.org/10.1093/eurheartj/ehx518

[31] Taskinen, M.-R.; Söderlund, S.; Bogl, L.H.; Hakkarainen, A.; Matikainen, N.; Pietiläinen, K.H.; Räsänen, S.; Lundbom, N.; Björnson, E.; Eliasson, B.; et al., 2017. Adverse effects of 
fructose on cardiometabolic risk factors and hepatic lipid metabolism in subjects with abdominal obesity. J. Intern. Med., 140, pp. 874-888.

[32] Schwarz, J.M.; Noworolski, S.M.; Wen, M.J.; Dyachenko, A.; Prior, J.L.; Weinberg, M.E.; Herraiz, L.A.; Tai, V.W.; Bergeron, N.; Bersot, T.P.; et al., 2015. Effect of a highfructose weight-maintaining diet on lipogenesis and liver fat. J. Clin. Endocrinol. Metab., 100, pp. 2434-2442. https://doi.org/10.1210/jc.2014-3678

[33] Faeh, D.; Minehira, K.; Schwarz, J.M.; Periasami, R.; Seongsu, P.; Tappy, L., 2005. Effect of fructose overfeeding and fish oil administration on hepatic de novo lipogenesis and insulin sensitivity in healthy men. Diabetes, 54, pp. 19071913. https://doi.org/10.2337/diabetes.54.7.1907

[34] Cox, C.L.; Stanhope, K.L.; Schwarz, J.M.; Graham, J.L.; Hatcher, B.; Griffen, S.C.; Bremer, A.A.; Berglund, L.; McGahan, J.P.; Havel, P.J.; et al., 2012. Consumption of fructose-sweetened beverages for 10 weeks reduces net fat oxidation and energy expenditure in overweight/obese men and women. Eur. J. Clin. Nutr., 66, pp. 201-208. https://doi.org/10.1038/ejcn.2011.159

[35] Maersk, M.; Belza, A.; Stodkilde-Jorgensen, H.; Ringgaard, S.; Chabanova, E.; Thomsen, H.; Pedersen, S.B.; Astrup, A.; Richelsen, B., 2012. Sucrose-sweetened beverages increase fat storage in the liver, muscle, and visceral fat depot: A 6-mo randomized intervention study. Am. J. Clin. Nutr., 95, pp. 283-289.

https://doi.org/10.3945/ajcn.111.022533

[36] Adiels, M.; Taskinen, M.-R.; Packard, C.; Caslake, M.J.; Soro-Paavonen, A.; Westerbacka, J.; Vehkavaara, S.; Hakkinen, A.; Olofsson, S.-O.; Yki-Jarvinen, H.; et al., 2006. Overproduction of large VLDL particles is driven by increased liver fat content in man. Diabetologia, 49, pp. 755765.

https://doi.org/10.1007/s00125-005-0125-z

[37] Chapman, M.J.; Le Goff, W.; Guerin, M.; Kontush, A., 2010. Cholesteryl ester transfer protein: At the heart of the action of lipid-modulating therapy with statins, fibrates, niacin, and cholesteryl ester transfer protein inhibitors. Eur. Heart J., 31, pp. 149-164.

https://doi.org/10.1093/eurheartj/ehp399

[38] Packard, C.J., 2003. Triacylglycerol-rich lipoproteins and the generation of small, dense low-density lipoprotein. Biochem. Soc. Trans., 31, pp. 1066-1069. https://doi.org/10.1042/bst0311066

[39] Zheng, C.; Khoo, C.; Furtado, J.; Sacks, F.M., 2010. Apolipoprotein C-III and the metabolic basis for hypertriglyceridemia and the dense low-density lipoprotein phenotype. Circulation, 121, pp. 1722-1734. https://doi.org/10.1161/CIRCULATIONAHA.109.875807

[40] Sacks, F.M., 2015. The crucial roles of apolipoproteins E and C-III in apoB lipoprotein metabolism in normolipidemia and hypertriglyceridemia. Curr. Opin. Lipidol., 26, pp. 56-63. https://doi.org/10.1097/MOL.0000000000000146

[41] Mendoza, S.; Trenchevska, O.; King, S.M.; Nelson, R.W.; Nedelkov, D.; Krauss, R.M.; Yassine, H.N., 2017. Changes in low-density lipoprotein size phenotypes associate with changes in apolipoprotein C-III glycoforms after dietary interventions. J. Clin. Lipidol., 11, pp. 224-233.e2. https://doi.org/10.1016/j.jacl.2016.12.009

[42] Bremer, A.A.; Stanhope, K.L.; Graham, J.L.; Cummings, B.P.; Wang, W.; Saville, B.R.; Havel, P.J., 2011. Fructose-fed rhesus monkeys: A nonhuman primate model of insulin resistance, metabolic syndrome, and type 2 diabetes. Clin. Transl. Sci., 4, pp. 243-252. https://doi.org/10.1111/j.1752-8062.2011.00298.x

[43] Stanhope, K.L.; Medici, V.; Bremer, A.A.; Lee, V.; Lam, H.D.; Nunez, M.V.; Chen, G.X.; Keim, N.L.; Havel, P.J., 2015. A dose-response study of consuming high-fructose corn syrup- sweetened beverages on lipid/lipoprotein risk factors for cardiovascular disease in young adults. Am. J. Clin. Nutr., 101, pp. 1144-1154. https://doi.org/10.3945/ajcn.114.100461

[44] Gonzalez-granda, A.; Damms-machado, A.; Basrai, M.; Bischoff, S.C., 2018. Changes in Plasma Acylcarnitine and Lysophosphatidylcholine Levels Following a High-Fructose Diet: A Targeted Metabolomics Study in Healthy Women. Nutrients, 10, p. 1254

https://doi.org/10.3390/nu10091254

[45] Teff, K.L.; Elliott, S.S.; Tschöp, M.; Kieffer, T.J.; Rader, D.; Heiman, M.; Townsend, R.R.; Keim, N.L.; D'Alessio, D.; Havel, P.J., 2004. Dietary fructose reduces circulating insulin and leptin, attenuates postprandial suppression of ghrelin, and increases triglycerides in women. J. Clin. Endocrinol. Metab., 89, pp. 2963-2972. https://doi.org/10.1210/jc.2003-031855

[46] Okazaki, M.; Usui, S.; Ishigami, M.; Sakai, N.; Nakamura, T.; Matsuzawa, Y.; Yamashita, S., 2005. Identification of unique lipoprotein subclasses for visceral obesity by component analysis of cholesterol profile in high-performance liquid chromatography. Arterioscler. Thromb. Vasc. Biol., 25, pp. 578-584.

https://doi.org/10.1161/01.ATV.0000155017.60171.88

[47] Toshima, G.; Iwama, Y.; Kimura, F.; Matsumoto, Y.; Miura, M., 2013. LipoSEARCH $\rightarrow$; Analytical GP-HPLC method for lipoprotein profiling and its applications. J. Biol. Macromol., 13, pp. 21-32.

[48] Araki, E.; Yamashita, S.; Arai, H.; Yokote, K.; Satoh, J.; Inoguchi, T.; Nakamura, J.; Maegawa, H.; Yoshioka, N.; Yukio, T.; et al., 2018. Effects of Pemafibrate, a Novel Selective PPAR $\alpha$ Modulator, on Lipid and Glucose Metabolism in Patients with Type 2 Diabetes and Hypertriglyceridemia: A Randomized, Double-Blind, PlaceboControlled, Phase 3 Trial. Diabetes Care, 41, pp. 538-546. https://doi.org/10.2337/dc17-1589

[49] Lee, S.J.; Campos, H.; Moye, L.A.; Sacks, F.M., 2003. LDL containing apolipoprotein CIII is an independent risk factor for coronary events in diabetic patients. Arterioscler. Thromb. Vasc. Biol., 23, pp. 853-858. https://doi.org/10.1161/01.ATV.0000066131.01313.EB

[50] Ooi, E.M.M.; Barrett, P.H.R.; Chan, D.C.; Watts, G.F., 2008. Apolipoprotein C-III: Understanding an emerging cardiovascular risk factor. Clin. Sci., 114, pp. 611-624. https://doi.org/10.1042/CS20070308

[51] Altomonte, J.; Cong, L.; Harbaran, S.; Richter, A.; Xu, J. Meseck, M.; Dong, H.H., 2004. Foxo1 mediates insulin action on apoC-III and triglyceride metabolism. J. Clin. Investig., 114, pp. 1493-1503. https://doi.org/10.1172/JCl200419992

[52] Stanhope, K.L.; Griffen, S.C.; Bremer, A.A.; Vink, R.G.; Schaefer, E.J.; Nakajima, K.; Schwarz, J.M.; Beysen, C.; Berglund, L.; Keim, N.L.; et al., 2011. Metabolic responses to prolonged consumption of glucose- and fructose-sweetened beverages are not associated with postprandial or 24-h glucose and insulin excursions. Am. J. Clin. Nutr., 94, pp. 112-119. https://doi.org/10.3945/ajcn.110.002246

[53] Caron, S.; Verrijken, A.; Mertens, I.; Samanez, C.H. Mautino, G.; Haas, J.T.; Duran-Sandoval, D.; Prawitt, J.; Francque, S.; Vallez, E.; et al., 2011. Transcriptional activation of apolipoprotein CIII expression by glucose may contribute to diabetic dyslipidemia. Arterioscler. Thromb. Vasc. Biol., 31, pp. 513-519. https://doi.org/10.1161/ATVBAHA.110.220723

[54] West, G.; Rodia, C.; Li, D.; Johnson, Z.; Dong, H.; Kohan, A.B., 2017. Key differences between apoC-III regulation and expression in intestine and liver. Biochem. Biophys. Res. Commun., 491, pp. 747-753. https://doi.org/10.1016/j.bbrc.2017.07.116 
[55] Kim, M.; Lai, M.; Herman, M.A.; Kim, M.; Krawczyk, S.A.; Doridot, L.; Fowler, A.J.; Wang, J.X.; Trauger, S.A.; Noh, H.; et al., 2016. ChREBP regulates fructose-induced glucose production independently of insulin signaling. J. Clin. Investig., 126, pp. 4372-4386. https://doi.org/10.1172/JCl81993

[56] Koo, H.Y.; Wallig, M.A.; Chung, B.H.; Nara, T.Y.; Cho, B.H.S.; Nakamura, M.T., 2008. Dietary fructose induces a wide range of genes with distinct shift in carbohydrate and lipid metabolism in fed and fasted rat liver. Biochim. Biophys. Acta Mol. Basis Dis., 1782, pp. 341-348.

\section{https://doi.org/10.1016/j.bbadis.2008.02.007}

[57] Ramms, B.; Gordts, P.L.S.M., 2018. Apolipoprotein C-III in triglyceride-rich lipoprotein metabolism. Curr. Opin. Lipidol., 29, pp. 171-179.

https://doi.org/10.1097/MOL.0000000000000502

[58] Butler, A.A.; Price, C.A.; Graham, J.L.; Stanhope, K.L.; King, S.; Hung, Y.-H.; Sethupathy, P.; Wong, S.; Hamilton, J.; Krauss, R.M.; et al., 2019. Fructose-induced hypertriglyceridemia in rhesus macaques is attenuated with fish oil or apoC3 RNA interference. J. Lipid Res., 60, p. jlr.M089508.

https://doi.org/10.1194/jlr.M089508

[59] Batal, R.; Tremblay, M.; Barrett, P.H.R.; Jacques, H.; Fredenrich, A.; Mamer, O.; Davignon, J.; Cohn, J.S., 2000. Plasma kinetics of apoC-III and apoE in normolipidemic and hypertriglyceridemic subjects. J. Lipid Res., 41, pp. 706-718. https://doi.org/10.1016/S0022-2275(20)32379-8

[60] Yao, Z., 2012. Human apolipoprotein C-III-A new intrahepatic protein factor promoting assembly and secretion of very low density lipoproteins. Cardiovasc. Hematol. Disord. Drug Targets, 12, pp. 133-140. https://doi.org/10.2174/1871529X11202020133

[61] Sundaram, M.; Yao, Z., 2010. Recent progress in understanding protein and lipid factors affecting hepatic VLDL assembly and secretion. Nutr. Metab., 7, pp. 1-17. https://doi.org/10.1186/1743-7075-7-35

[62] Sundaram, M.; Curtis, K.R.; Amir Alipour, M.; LeBlond, N.D.; Margison, K.D.; Yaworski, R.A.; Parks, R.J.; McIntyre, A.D.; Hegele, R.A.; Fullerton, M.D.; et al., 2017. The apolipoprotein C-III (GIn38Lys) variant associated with human hypertriglyceridemia is a gain-of-function mutation. J. Lipid Res., 58, pp. 2188-2196.

https://doi.org/10.1194/jlr.M077313

[63] Matikainen, N.; Adiels, M.; Söderlund, S.; Stennabb, S.; Ahola, T.; Hakkarainen, A.; Borén, J.; Taskinen, M.R., 2014. Hepatic lipogenesis and a marker of hepatic lipid oxidation, predict postprandial responses of triglyceride-rich lipoproteins. Obesity, 22, pp. 1854-1859.

https://doi.org/10.1002/oby.20781

[64] Gordts, P.L.S.M.; Nock, R.; Son, N.-H.; Ramms, B.; Lew, I.; Gonzales, J.C.; Thacker, B.E.; Basu, D.; Lee, R.G.; Mullick, A.E.; et al., 2016. ApoC-III Modulates Clearance of Triglyceride-Rich Lipoproteins in Mice Through Low Density Lipoprotein Family Receptors. J. Clin. Investig., 126, pp. 2855-2866.

https://doi.org/10.1172/JCl86610

[65] Talayero, B.; Wang, L.; Furtado, J.; Carey, V.J.; Bray, G.A.; Sacks, F.M., 2014. Obesity favors apolipoprotein E- and CIII-containing high density lipoprotein subfractions associated with risk of heart disease. J. Lipid Res., 55, pp. 2167-2177. https://doi.org/10.1194/jlr.M042333

[66] Hodis, H.N., 1999. Triglyceride-rich lipoprotein remnant particles and risk of atherosclerosis. Circulation, 99, pp. 2852-2854.

https://doi.org/10.1161/01.CIR.99.22.2852

[67] Sacks, F.M.; Alaupovic, P.; Moye, L.A.; Cole, T.G.; Sussex, B.; Stampfer, M.J.; Pfeffer, M.A.; Braunwald, E., 2000. VLDL, apolipoproteins $\mathrm{B}, \mathrm{CIII}$, and $\mathrm{E}$, and risk of recurrent coronary events in the Cholesterol and Recurrent Events (CARE) trial.
Circulation, 102, pp. 1886-1892.

https://doi.org/10.1161/01.CIR.102.16.1886

[68] Sharrett, A.R.; Heiss, G.; Chambless, L.E.; Boerwinkle, E.; Coady, S.A.; Folsom, A.R.; Patsch, W., 2001. Metabolic and lifestyle determinants of postprandial lipemia differ from those of fasting triglycerides the Atherosclerosis Risk in Communities (ARIC) study. Arterioscler. Thromb. Vasc. Biol., 21, pp. 275-281. https://doi.org/10.1161/01.ATV.21.2.275

[69] Bansal, S.; Buring, J.E.; Rifai, N.; Mora, S.; Sacks, F.M.; Ridker, P.M., 2007. Fasting compared with nonfasting triglyceride and risk of cardiovascular events in women. JAMA, 298, pp. 309-316.

https://doi.org/10.1001/jama.298.3.309

[70] Nordestgaard, B.G.; Benn, M.; Schnohr, P.; Tybjærg-hansen, A., 2007. Nonfasting Triglycerides and Risk of Myocardial Infarction, Ischemic Heart. JAMA, 298, pp. 299-308. https://doi.org/10.1001/jama.298.3.299

[71] Varbo, A.; Freiberg, J.J.; Nordestgaard, B.G., 2015. Extreme nonfasting remnant cholesterol vs extreme LDL cholesterol as contributors to cardiovascular disease and all-cause mortality in 90000 individuals from the general population. Clin. Chem., 61, pp. 533-543.

https://doi.org/10.1373/clinchem.2014.234146

[72] Haidari, M.; Leung, N.; Mahbub, F.; Uffelman, K.D.; KohenAvramoglu, R.; Lewis, G.F.; Adeli, K., 2002. Fasting and postprandial overproduction of intestinally derived lipoproteins in an animal model of insulin resistance: Evidence that chronic fructose feeding in the hamster is accompanied by enhanced intestinal de novo lipogenesis and ApoB48-containing li. J. Biol. Chem., 277, pp. 3164631655. https://doi.org/10.1074/jbc.M200544200

[73] Steenson, S.; Umpleby, A.M.; Lovegrove, J.A.; Jackson, K.G.; Fielding, B.A., 2017. Role of the enterocyte in fructoseinduced hypertriglyceridaemia. Nutrients, 9 , pp. 349. https://doi.org/10.3390/nu9040349

[74] Nestel, P.J.; Fidge, N.H., 1982. Apoprotein C Metabolism in Man. Adv. Lipid Res., 19, pp. 55-83. https://doi.org/10.1016/B978-0-12-024919-0.50008-4

[75] Wolska, A.; Dunbar, R.L.; Freeman, L.A.; Ueda, M.; Amar, M.J.; Sviridov, D.O.; Remaley, A.T., 2017. Apolipoprotein CII: New findings related to genetics, biochemistry, and role in triglyceride metabolism. Atherosclerosis, 267, pp. 49-60. https://doi.org/10.1016/j.atherosclerosis.2017.10.025

[76] Taskinen, M.R., 2003. Diabetic dyslipidaemia: From basic research to clinical practice. Diabetologia, 46, pp. 733-749. https://doi.org/10.1007/s00125-003-1111-y

[77] Eisenberg, S., 1985. Preferential enrichment of large-sized very low density lipoprotein populations with transferred cholesteryl esters. J. Lipid Res., 26, pp. 487-494. https://doi.org/10.1016/S0022-2275(20)34364-9

[78] Krauss, R.M., 2005. Dietary and genetic probes of atherogenic dyslipidemia. Arterioscler. Thromb. Vasc. Biol., 25, pp. 2265-2272.

https://doi.org/10.1161/01.ATV.0000186365.73973.f0

[79] Adiels, M.; Olofsson, S.O.; Taskinen, M.R.; Borén, J., 2008. Overproduction of very low-density lipoproteins is the hallmark of the dyslipidemia in the metabolic syndrome. Arterioscler. Thromb. Vasc. Biol. 28, pp. 1225-1236. https://doi.org/10.1161/ATVBAHA.107.160192

[80] Berneis, K.K.; Krauss, R.M., 2002. Metabolic origins and clinical significance of LDL heterogeneity. J. Lipid Res. 43, pp. $1363-1379$. https://doi.org/10.1194/jlr.R200004-JLR200

[81] Berneis, K.; Rizzo, M.; Spinas, G.A.; Di Lorenzo, G.; Di Fede, G.; Pepe, I.; Pernice, V.; Rini, G.B., 2009. The predictive role of atherogenic dyslipidemia in subjects with non-coronary atherosclerosis. Clin. Chim. Acta, 406, pp. 36-40. https://doi.org/10.1016/j.cca.2009.05.002 
[82] Rizzo, M.; Pernice, V.; Frasheri, A.; Di Lorenzo, G.; Rini, G.B.; Spinas, G.A.; Berneis, K., 2009. Small, dense lowdensity lipoproteins (LDL) are predictors of cardio- and cerebro-vascular events in subjects with the metabolic syndrome. Clin. Endocrinol., 70, pp. 870-875. https://doi.org/10.1111/j.1365-2265.2008.03407.x

[83] Ivanova, E.A.; Myasoedova, V.A.; Melnichenko, A.A.; Grechko, A.V.; Orekhov, A.N., 2017. Small Dense LowDensity Lipoprotein as Biomarker for Atherosclerotic Diseases. Oxid. Med. Cell. Longev., 2017, p. 1273042. https://doi.org/10.1155/2017/1273042

[84] Xiao, C.; Dash, S.; Morgantini, C.; Hegele, R.A.; Lewis, G.F., 2016. Pharmacological targeting of the atherogenic dyslipidemia complex: The next frontier in CVD prevention beyond lowering LDL cholesterol. Diabetes, 65, pp. 17671778.

https://doi.org/10.2337/db16-0046

[85] Aeberli, I.; Hochuli, M.; Gerber, P., 2013. Moderate Amounts of Fructose Consumption Impair Insulin Sensitivity in Healthy Young Men A randomized controlled trial. Diabetes Care, 36, pp. 150-156.

https://doi.org/10.2337/dc12-0540

[86] Aeberli, I.; Gerber, P.A.; Hochuli, M.; Kohler, S.; Haile, S.R.; Gouni-Berthold, I.; Berthold, H.K.; Spinas, G.A.; Berneis, K., 2011. Low to moderate sugar-sweetened beverage consumption impairs glucose and lipid metabolism and promotes inflammation in healthy young men: A randomized controlled trial. Am. J. Clin. Nutr., 94, pp. 479-485. https://doi.org/10.3945/ajcn.111.013540

[87] Pasquel, F.J.; Spiegelman, R.; McCauley, M.; Smiley, D.; Umpierrez, D.; Johnson, R.; Rhee, M.; Gatcliffe, C.; Lin, E.; Umpierrez, E.; et al., 2010. Hyperglycemia during total parenteral nutrition: An important marker of poor outcome and mortality in hospitalized patients. Diabetes Care, 33, pp. 739-741.

https://doi.org/10.2337/dc09-1748

[88] Davidson, P.; Kwiatkowski, C.A.; Wien, M., 2015. Management of Hyperglycemia and Enteral Nutrition in the Hospitalized Patient. Nutr. Clin. Pract., 30, pp. 652-659. https://doi.org/10.1177/0884533615591057

[89] Pleva, M.; Mirtallo, J.M.; Steinberg, S.M., 2009. Hyperglycemic events in non-intensive care unit patients receiving parenteral nutrition. Nutr. Clin. Pract., 24, pp. 626634.

https://doi.org/10.1177/0884533609339069

[90] Pancorbo-Hidalgo, P.L.; Garcia-Fernandez, F.P.; RamirezPerez, C., 2001. Complications associated with enteral nutrition by nasogastric tube in an internal medicine unit. J. Clin. Nurs., 10, pp. 482-490. https://doi.org/10.1046/j.1365-2702.2001.00498.x

[91] McCowen, K.C.; Malhotra, A.; Bistrian, B.R., 2001. StressInduced Hyperglycemia. J. Clin. Nurs., 17, pp. 107-124. https://doi.org/10.1016/S0749-0704(05)70154-8

[92] Herrmann, C.; Göke, R.; Richter, G.; Fehmann, H.C.; Arnold, R.; Göke, B., 1995. Glucagon-Like Peptide-1 and GlucoseDependent Insulin-Releasing Polypeptide Plasma Levels in Response to Nutrients. Digestion, 56, pp. 117-126. https://doi.org/10.1159/000201231

[93] Andrews, R.C.; Walker, B.R., 1999. Glucocorticoids and insulin resistance: Old hormones, new targets. Clin. Sci., 96, pp. 513-523.

https://doi.org/10.1042/cs0960513

[94] Marathe, C.S.; Rayner, C.K.; Bound, M.; Checklin, H.; Standfield, S.; Wishart, J.; Lange, K.; Jones, K.L.; Horowitz, M., 2014. Small intestinal glucose exposure determines the magnitude of the incretin effect in health and type 2 diabetes. Diabetes, 63, pp. 2668-2675. https://doi.org/10.2337/db13-1757

[95] Olveira, G.; Tapia, M.J.; Ocón, J.; Cabrejas-Gómez, C.; Ballesteros-Pomar, M.D.; Vidal-Casariego, A.; Arraiza-
Irigoyen, C.; Olivares, J.; Conde-García, M.e.C.; GarcíaManzanares, A.; et al., 2013. Parenteral nutrition-associated hyperglycemia in non-critically ill inpatients increases the risk of in-hospital mortality (multicenter study). Diabetes Care, 36, pp. 1061-1066.

[96] Lin, L.Y.; Lin, H.C.; Lee, P.C.; Ma, W.Y.; Lin, H.D., 2007 Hyperglycemia correlates with outcomes in patients receiving total parenteral nutrition. Am. J. Med Sci., 333, pp. 261-265. https://doi.org/10.1097/MAJ.0b013e3180536b26

[97] Cheung, N.W.; Napier, B.; Zaccaria, C.; Fletcher, J.P., 2005. Hyperglycemia is associated with adverse outcomes in patients receiving total parenteral nutrition. Diabetes Care, 28 , pp. 2367-2371.

https://doi.org/10.2337/diacare.28.10.2367

[98] Yuan, J.; Liu, T.; Zhang, X.; Si, Y.; Ye, Y.; Zhao, C.; Wang, Q.; Shen, X., 2015. Intensive Versus Conventional Glycemic Control in Patients with Diabetes During Enteral Nutrition After Gastrectomy. J. Gastrointest. Surg. 19, pp. 1553-1558. https://doi.org/10.1007/s11605-015-2871-7

[99] Murad, M.H.; Coburn, J.A.; Coto-Yglesias, F.; Dzyubak, S.; Hazem, A.; Lane, M.A.; Prokop, L.J.; Montori, V.M., 2012 Glycemic Control in Non-Critically III Hospitalized Patients: A Systematic Review and Meta-Analysis. J. Clin. Endocrinol. Metab., 97, pp. 49-58. https://doi.org/10.1210/jc.2011-2100

[100] Kang, Z.-Q.; Huo, J.-L.; Zhai, X.-J., 2018. Effects of perioperative tight glycemic control on postoperative outcomes: A meta-analysis. Endocr. Connect., 7, pp. R316R327. https://doi.org/10.1530/EC-18-0231

[101] Umpierrez, G.E.; Smiley, D.; Zisman, A.; Prieto, L.M.; Palacio, A.; Ceron, M.; Puig, A.; Mejia, R., 2007. Randomized Study of Basal-Bolus Insulin Therapy in the Inpatient Management of Patients with Type 2 Diabetes (RABBIT 2 Trial). Diabetes Care, 30, p. 2181. https://doi.org/10.2337/dc07-0295

[102] Turchin, A.; Matheny, M.E.; Shubina, M.; Scanlon, J.V.; Greenwood, B.; Pendergrass, M.L., 2009. Hypoglycemia and clinical outcomes in patients with diabetes hospitalized in the general ward. Diabetes Care, 32, pp. 1153-1157. https://doi.org/10.2337/dc08-2127

[103] Finfer, S.; Chittock, D.R.; Su, S.Y.; Blair, D.; Foster, D.; Dhingra, V.; Bellomo, R.; Cook, D.; Dodek, P.; Henderson, W.R.; et al., 2009. Intensive versus Conventional Glucose Control in Critically III Patients. N. Engl. J. Med., 360, pp. 1283-1297. https://doi.org/10.1056/NEJMoa0810625

[104] Association, A.D., 2019. 15. Diabetes Care in the Hospital. Diabetes Care, 42, pp. S173-S181.

[105] Umpierrez, G.E.; Hellman, R.; Korytkowski, M.T.; Kosiborod, M.; Maynard, G.A.; Montori, V.M.; Seley, J.J.; Van den Berghe, G.; Society, E., 2012. Management of hyperglycemia in hospitalized patients in non-critical care setting: An endocrine society clinical practice guideline. J. Clin. Endocrinol. Metab., 97, pp. 16-38.

https://doi.org/10.1210/jc.2011-2098

[106] McCulloch, A.; Bansiya, V.; Woodward, J.M., 2018. Addition of Insulin to Parenteral Nutrition for Control of Hyperglycemia. JPEN, 42, pp. 846-854. https://doi.org/10.1177/0148607117722750

[107] Aragon, D., 2006. Evaluation of nursing work effort and perceptions about blood glucose testing in tight glycemic control. Am. J. Crit. Care, 15, pp. 370-377. https://doi.org/10.4037/ajcc2006.15.4.370

[108] Elia, M.; Ceriello, A.; Laube, H.; Sinclair, A.J.; Engfer, M.; Stratton, R.J., 2005. Enteral nutritional support and use of diabetes-specific formulas for patients with diabetes: A systematic review and meta-analysis. Diabetes Care, 28, pp. 2267-2279.

https://doi.org/10.2337/diacare.28.9.2267 
[109] Ojo, O.; Brooke, J., 2014. Evaluation of the role of enteral nutrition in managing patients with diabetes: A systematic review. Nutrients, 6, pp. 5142-5152. https://doi.org/10.3390/nu6115142

[110] Rodbard, D., 2017. Continuous Glucose Monitoring: A Review of Recent Studies Demonstrating Improved Glycemic Outcomes. Diabetes Technol. Ther., 19, S25-S37. https://doi.org/10.1089/dia.2017.0035

[111] Pickup, J.C. Insulin-pump therapy for type 1 diabetes mellitus. N. Engl J. Med. 2012, 366, pp. 1616-1624. https://doi.org/10.1056/NEJMct1113948

[112] Bally, L.; Thabit, H.; Hovorka, R., 2017. Closed-loop for type 1 diabetes-an introduction and appraisal for the generalist. BMC Med., 15, p. 14 https://doi.org/10.1186/s12916-017-0794-8

[113] Bally, L.; Thabit, H.; Hovorka, R., 2017. Glucose-responsive insulin delivery for type 1 diabetes: The artificial pancreas story. Int. J. Pharm. https://doi.org/10.1016/j.ijpharm.2017.12.022

[114] Moher, D.; Liberati, A.; Tetzlaff, J.; Altman, D.G.; Group, P., 2010. Preferred reporting items for systematic reviews and meta-analyses: The PRISMA statement. Int. J. Surg., 8, pp. 336-341. https://doi.org/10.1016/j.ijsu.2010.02.007

[115] Stroup, D.F.; Berlin, J.A.; Morton, S.C.; Olkin, I.; Williamson, G.D.; Rennie, D.; Moher, D.; Becker, B.J.; Sipe, T.A.; Thacker, S.B.; et al., 2000, Meta-analysis of Observational Studies in EpidemiologyA Proposal for Reporting. JAMA, 283, pp. 2008-2012. https://doi.org/10.1001/jama.283.15.2008

[116] Higgins, J.P.T.; Altman, D.G.; Gøtzsche, P.C.; Jüni, P.; Moher, D.; Oxman, A.D.; Savović, J.; Schulz, K.F.; Weeks, L.; Sterne, J.A.C., 2011. The Cochrane Collaboration's tool for assessing risk of bias in randomized trials. BMJ, 343, p. d5928.

https://doi.org/10.1136/bmj.d5928

[117] Boughton, C.K.; Bally, L.; Martignoni, F.; Hartnell, S.; Herzig, D.; Vogt, A.; Wertli, M.M.; Wilinska, M.E.; Evans, M.L.; Coll, A.P.; et al., 2019. Fully closed-loop insulin delivery in inpatients receiving nutritional support: A two-center, openlabel, randomized controlled trial. Lancet Diabetes Endocri., 7, pp. 368-377. https://doi.org/10.1016/S2213-8587(19)30061-0

[118] Olveira, G.; Abuin, J.; Lopez, R.; Herranz, S.; GarciaAlmeida, J.M.; Garcia-Malpartida, K.; Ferrer, M.; Cancer, E.; Luengo-Perez, L.M.; Alvarez, J.; et al. Regular insulin added to total parenteral nutrition vs. subcutaneous glargine in non- critically ill diabetic inpatients, a multicenter randomized clinical trial: INSUPAR trial. Clin. Nutr. 2019.

[119] Hakeam, H.A.; Mulia, H.A.; Azzam, A.; Amin, T., 2017. Glargine Insulin Use Versus Continuous Regular Insulin in Diabetic Surgical Noncritically III Patients Receiving Parenteral Nutrition: Randomized Controlled Study. JPEN, 41, pp. 1110-1118. https://doi.org/10.1177/0148607116644710

[120] Lidder, P.; Flanagan, D.; Fleming, S.; Russell, M.; Morgan, N.; Wheatley, T.; Rahamin, J.; Shaw, S.; Lewis, S., 2010. Combining enteral with parenteral nutrition to improve postoperative glucose control. Br. J. Nutr., 103, pp. 16351641.

https://doi.org/10.1017/S0007114509993631

[121] Tiyapanjanit, T.; Boonyavarakul, A., 2014. Comparative study between the Phramongkutklao's diabetic blenderized diets and commercial diabetic diets on glycemic variability in continuous tube fed patients with type 2 diabetes. J. Med. Assoc. Thai., 97, pp. 1151-1156.

[122] Leon-Sanz, M.; Garcia-Luna, P.P.; Sanz-Paris, A.; GomezCandela, C.; Casimiro, C.; Chamorro, J.; Pereira-Cunill, J.L.; Martin-Palmero, A.; Trallero, R.; Martinez, J.; et al., 2005. Glycemic and lipid control in hospitalized type 2 diabetic patients: Evaluation of 2 enteral nutrition formulas (low carbohydrate-high monounsaturated fat vs. high carbohydrate). JPEN, 29, pp. 21-29. https://doi.org/10.1177/014860710502900121

[123] Li, F.F.; Zhang, W.L.; Liu, B.L.; Zhang, D.F.; Chen, W.; Yuan, L.; Chen, M.Y.; Zhai, X.F.; Wu, J.D.; Su, X.F.; et al., 2018 Management of glycemic variation in diabetic patients receiving parenteral nutrition by continuous subcutaneous insulin infusion (CSII) therapy. Sci. Rep., 8, p. 5888. https://doi.org/10.1038/s41598-018-24275-5

[124] Kruyt, N.D.; Biessels, G.J.; Vriesendorp, T.M.; Devries, J.H.; Hoekstra, J.B.; Elbers, P.W.; Kappelle, L.J.; Portegies, P.; Vermeulen, M.; Roos, Y.B., 2010. Subjecting acute ischemic stroke patients to continuous tube feeding and an intensive computerized protocol establishes tight glycemic control. Neurocrit. Care, 12, pp. 62-68. https://doi.org/10.1007/s12028-009-9230-z

[125] Korytkowski, M.T.; Salata, R.J.; Koerbel, G.L.; Selzer, F.; Karslioglu, E.; Idriss, A.M.; Lee, K.K.; Moser, A.J.; Toledo, F.G., 2009. Insulin therapy and glycemic control in hospitalized patients with diabetes during enteral nutrition therapy: A randomized controlled clinical trial. Diabetes Care, 32, pp. 594-596. https://doi.org/10.2337/dc08-1436

DOI: https://doi.org/10.15379/2410-1869.2021.08.02.04

(c) 2021 Alireza Heidari; Licensee Cosmos Scholars Publishing House.

This is an open access article licensed under the terms of the Creative Commons Attribution Non-Commercial License

(http://creativecommons.org/licenses/by-nc/3.0/), which permits unrestricted, non-commercial use, distribution and reproduction in any medium, provided the work is properly cited. 